\title{
Is there a new institutional response to the crimes of Communism? National memory agencies in post-Communist countries: the Polish case (1998-2014), with references to East Germany
}

\author{
Georges Mink ${ }^{\mathrm{a}, \mathrm{b} *}$ \\ ${ }^{a}$ ISP-CNRS, Paris, France; ${ }^{b}$ College of Europe, Natolin Campus, Warszawa, Poland
}

(Received 16 November 2016; accepted 31 March 2017)

\begin{abstract}
Post-Communist Europe has not chosen to imitate the Truth and Justice or Truth and Reconciliation Commissions set up on several other continents. The notion of reconciliation with the Communist regime is not of much interest to certain political parties, many of which are rooted in the protest against the compromises that were part of the negotiated revolutions. The model admired by post-Communist countries was the one conceived by the Germans. Almost all the countries founded specific institutions - institutes - for managing memory, with archives located in these institutes. Some have archives that date from before World War II to 1990; they handle both totalitarianisms. What is feared is that through the game of partisan appointments, these institutes will become little more than instruments in less than honest hands for use in political contests. This is especially likely given that the Polish Institute of National Memory (IPN) employees perform several functions: classification, prosecution, and evaluating individual applicants to certain administrative positions. The specialized literature usually explains the trials and tribulations of Poland's IPN in terms of the personalities of its different directors and the period in which each occupied that post. In this paper, we have verified this hypothesis.
\end{abstract}

Keywords: Poland; GDR; Institutions for National Remembrance (INR); memory games; post-Communism; lustration

We need to realize that this extraordinary situation will come to an end one day: IPN will not exist forever.... This need, this extraordinary state of affairs will one day come to an end. (Lukasz Kaminsky, third elected director of Poland's IPN, 2010)

This office is still necessary, and it will remain so as long as there is a social demand for coming to terms with the dictatorship and as long as there is a need to study how that dictatorship operated. (Rolan Jahn, third elected director of Germany's BStU [Behörde des Bundesbeauftragten für Stasiunterlagen der ehmalingen DDR], 2011)

Historians are free to choose research objects that interest them. But the state is under an obligation to account for the past. Citizens ... have been victimized by the two major totalitarianisms of the twentieth century. And victims demand truth, justice and memory. (Krzysztof Persak, historian, chief of staff to the third IPN director, 2012)

In 2014, the Polish center-left weekly Polityka published a long article on the IPN - "Institute of National Remembrance" is the official name in English - focused on the delicate

*Email: mink@u-paris10.fr 
question of conditions for gaining access to sensitive documents produced by political police functionaries prior to 1989. The article, entitled "The IPN extraction industry," was illustrated with a photomontage representing a miner in work clothes driving a pneumatic drill into orderly rows of documents as if to extract some metallic ore. The image of course well represents the cultural metaphor of "memory mines" by means of which we can represent the dynamic sociology that may be involved in lieux de mémoire [places of memory] (Nora 1984), places exploited politically either for purposes of solemn remembrance or reconciliation or, on the contrary, to fan the flames of conflicts and divisions between segments of a national society or different states in the name of a competitive, memory-based geopolitics. ${ }^{1}$ The case of national memory institutes is quite particular in that it involves deliberate construction of a combined place of memory, a 'memory mine.' Memory institutes resemble natural history museums where several species (episodes) of a painful history are exhibited (literally, documents attesting to crimes against the nation), extinct or endangered species kept alive so as to attest to the past and punish perpetrators of crimes committed under the two "totalitarianisms."

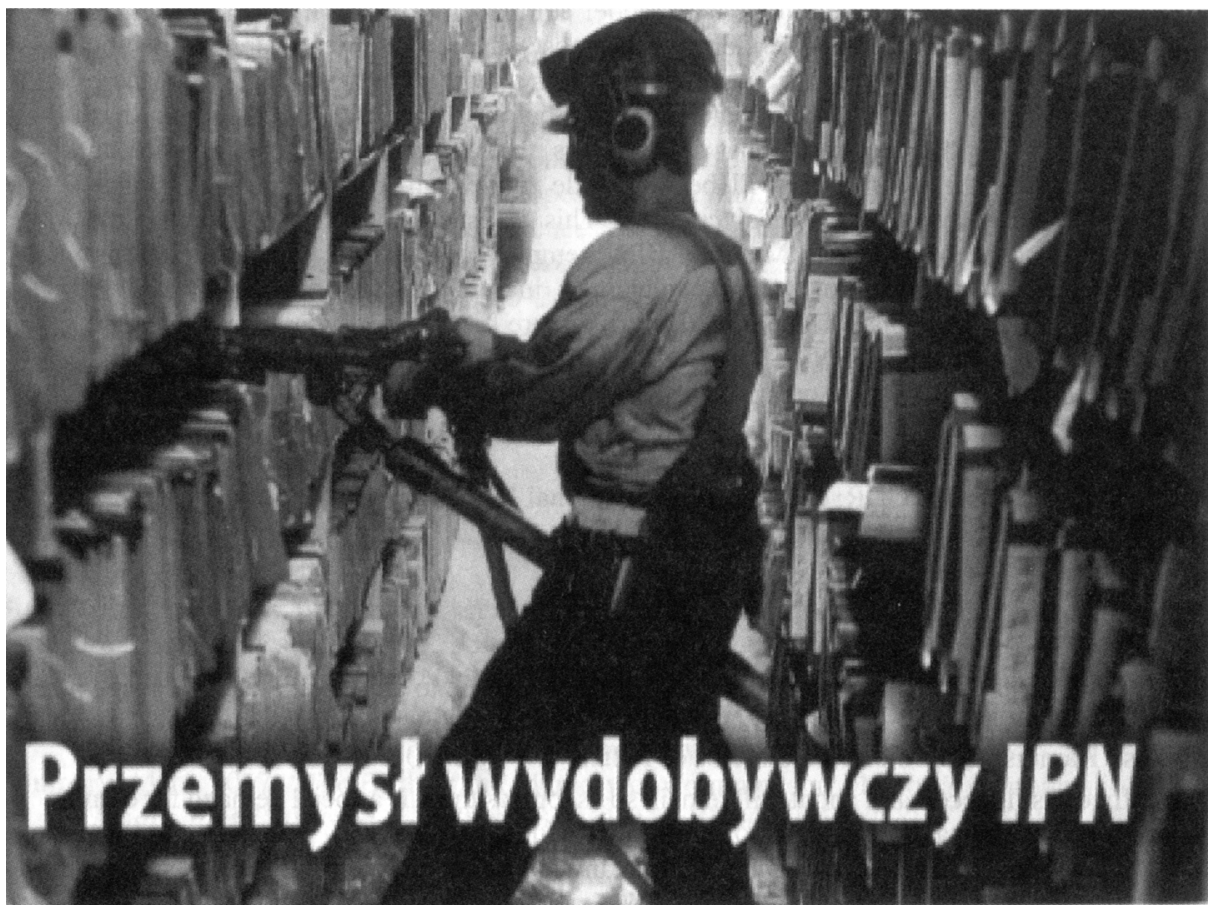

From Pytlakowski (2014).

All the former Communist countries without exception have had to face the problem of how to manage their past. The issue has manifested itself in many ways, from a demand to punish persons guilty of crimes and exactions to a demand for victim reparation, from intense concern about how to de-communize structures and probe and check the pasts of agents applying to work in those structures (the process known as lustration) to questions on how to transmit memory of what the Communist regime was like. The different countries have all adopted comparable solutions. All of them set up institutions in response to those demands; specifically, they established agencies for managing archives and 
investigating Communist crimes. And though these agencies were founded at different moments, they exhibit a certain institutional isomorphism, due to the similarity of social and political demands and to the fact that all countries took inspiration first from the German model and later the Polish one. But they have also produced a kind of institutional irredentism as an effect of each country's specific political situation.

\section{The Polish case}

The Institute of National Remembrance - Commission for the Prosecution of Crimes against the Polish Nation, hereafter designated IPN, was created by law on 18 December $1998 .^{2}$ The institute was assigned three official tasks: archive management, education of the public, and legal action.

To understand what is at issue in this highly atypical institution with its hybrid structure and multiple purposes, we need to recall the socio-historical context that followed on the compromise reached at the 1989 roundtable talks. Several components of that context are of importance here. First, the vicissitudes of the debate on how to manage the Communist past and what attitude the new democratic regime should adopt toward victims and executioners. One point debated at the time was how to educate civil society, how best to transmit memory of this past to the citizens - in other words, what history-related public policies should be implemented. The community of historians contributed to deliberations on what type of narrative or account should be preferred, what events should be emphasized, and from what angles events should be presented. In sum, how should the past be represented? As we shall see, these debates and the decisions reached varied with changes in political leadership. Those changes therefore shed light on how IPN operates.

The specialized literature usually explains the trials and tribulations of Poland's IPN in terms of the personalities of its different directors and the period in which each occupied that post. This explanation is also understood to apply to the rotation of heads of analogous institutions in Slovakia, the Czech Republic, Ukraine, and Germany (Mink and Neumayer 2013, 153-173).

Two non-contradictory hypotheses can be formulated on this point:

(1) Such institutions cannot fundamentally change from one period to another or from one director to another unless their official, legal attributes change; that is, their jurisdiction, missions, and structure.

(2) On the other hand, from a neo-institutionalist perspective, such institutions can be observed to adapt to their external contexts, including memory issues, and in response to their own internal institutional tensions.

Clearly, structural changes are dependent on who holds legislative power.

\section{The context}

At the 1989 Polish roundtable talks to negotiate an exit from Communism, the question of what to do with the past - a matter that is traditionally part of the action repertoire of transition agents - was left out. The talks produced no recommendations on how best to handle the criminal past of the ancien régime. The Polish compromise was implicitly modeled on the Spanish solution: yesterday's adversaries become the guarantors of tomorrow's democratization process. With one substantive difference, summed up by Adam Michnik as follows: in Poland the "amnesty and amnesia" principle became "amnesty, yes; amnesia, 
no" (Michnik, 7-10 April $1999^{3}$ ). Early on in the transformation process, the maneuvering room of those in favor of penal sanctions against the "criminal" Communist past was deliberately limited. This explains Poland's legislative and institutional indetermination and wavering with regard to managing that past.

In fact, public opinion, politicians' behavior, and legislative decision-making and policy were influenced at the time by two factors. First, the pressure of solutions for managing the past being defined by other former Communist countries, specifically East Germany; second, the consolidation of a political opposition group whose identity was defined by its total or partial rejection of the compromises reached at the roundtable talks.

\section{IPN was not born ex nihilo}

Chronologically, the idea of assigning the task of dealing with the Communist regime's criminal past to an ad hoc institution arose after demands were made to "lustrate" political personnel and rehabilitate those who had been persecuted under that regime. As early as February 1991, the Sejm (the lower chamber of parliament), dominated at that time by the different groups that had developed in connection with Solidarnosc, voted to annul all court sentences meted out against opponents who had fought for Polish state sovereignty. ${ }^{4}$ That same year, the procedure for trying perpetrators of Stalinist crimes got underway (see note 6). From 1991 to 1999, 1145 legal investigations were conducted in this connection as noted on the IPN website.

In June 1992, a first, spontaneous, and unofficial attempt at lustration was made. Interior minister Antoni Macierewicz took the legislators by surprise and tried to force their hand by publishing a list of supposed political police agents. The move proved counterproductive, provoking strong public indignation that ultimately left Jan Olszewski's government no choice but to resign. According to many commentators, the effect was to postpone for several years any real debate in Poland on how to deal with the past. Other commentators claim that with the victory of the former Communist Aleksander Kwasniewski, elected on the campaign slogan, "Let's choose the future," the question of appraising the different aspects of the Communist past was obliterated. Those most committed to getting the question of establishing an institution to deal with the past onto the political agenda were a small number of former Solidarnosc movement activists. Their reference point was the German model. Professor Witold Kulesza, Professor Andrzej Rzeplinski, and the historian Andrzej Paczkowski, who developed the initial project, enjoyed the support of Janusz Palubicki, a former Solidarnosc director and Minister of the Interior in the AWS Solidarnosc government, a coalition of groups that had developed out of the " $S$ " union. Marian Krzaklewski, the political leader of the AWS movement, organized intense parliamentary lobbying in favor of the idea, while Prime Minister Jerzy Buzek secured state funding for the project.

The path-dependence approach to transition is highly relevant for understanding IPN construction, as is an approach in terms of "recombining" old and new in the transformation of a pre-existing institution already active under the Communist regime: in this case the Central Commission for Investigation of Nazi crimes in Poland (Glowna Komisja Badania Zbrodni Hitlerowskich or GKBZH), in charge of investigating and prosecuting crimes committed during World War II. IPN inherited the Commission's archives, its library, and a set of prosecutors. Under the more general name of Commission for the Prosecution of Crimes Against the Polish Nation, that institution extended its repertoire in the 1990s to encompass Stalinist crimes. Prosecuting those crimes thus became one of IPN's official responsibilities. The Central Commission for the Prosecution of Crimes against 
the Polish Nation (Główna Komisja Ścigania Zbrodni przeciwko Narodowi Polskiemu or GKSZpNP) was set up as IPN's investigating unit, in compliance with the decree of 18 December 1998 (see note 2). It was also part of the Prokuratura of the Polish Republic, an institution headed by the Prosecutor-General in the person of the Minister of Justice. The head of the central commission bore the title of Assistant Prosecutor-General to the Prosecutor-General. He is the hierarchical superior of all prosecutors employed at the Central Commission and regional commissions. The GKSZpNP together with its 11 regional commissions located throughout Polish territory perform legal investigations into crimes against Polish citizens of Polish or other origin committed between 1 September 1939, and 31 July 1990. The crimes are identified in Article 1 of the Decree on IPN as Nazi crimes, Communist crimes, crimes against humanity, war crimes, and crimes against peace. (Some critics of the decree contest the closing date of the period, scandalized by the fact that it encompasses Tadeusz Mazowiecki's first non-Communist government; see Romanowski 2012.)

The GKSZpNP continues the activity of the Central Commission for the Investigation of German Crimes in Poland (Głównej Komisji Badania Zbrodni Niemieckich w Polsce, or GKBZNP), created in 1945 and assigned to collect documentation for trying Nazis for crimes committed during World War II. In 1949, the name of the commission was changed to the Central Commission for Investigation of Nazi Crimes in Poland (Główną Komisję Badania Zbrodni Hitlerowskich (GKBZH) w Polsce). Under this name, it investigated and instigated investigations until 1991. In that year, the name was changed once more, in compliance with the Decree of April 4, 1991 (Dz. U. 91.45.195), becoming the Central Commission for Investigation of Crimes against the Polish Nation-Institute of National Remembrance (Główna Komisja Badania Zbrodni przeciwko Narodowi Polskiemu - Instytut Pamięci Narodowej or GKBZpNP-IPN). The decree widened the Commission's jurisdiction and the scope of its investigations. Above and beyond Nazi crimes, it was now called upon to investigate "Stalinist" crimes together with other imprescriptible crimes against Polish citizens of non-Polish origin committed between 1939 and 1956.

Between 2000 and the first quarter of 2009, the Commission for Investigation of Crimes against the Polish Nation conducted 6300 preliminary legal investigations leading to 242 formal accusations against 385 perpetrators and 67,397 witnesses were interviewed in the course of these investigations. ${ }^{5}$

The alloying of old and new components - notably, the maintaining of the judiciary function inherited from the Communist period - represents one of the major differences between this institution and its counterparts in other former Communist countries in Europe. The emphasis placed on the legal mission within the overall institution (despite widespread criticism calling for the Commission to be integrated into the country's judiciary system) is therefore in no way a post-Communist invention. A kind of path-dependence can also be discerned in the German case with regard to the transmission of experience. The example of how the Nazi past was handled in Germany was crucial in shaping the German institution and its procedures: "the failure of de-Nazification considerably impacted the post-1989 debate on how to deal with the communist past" (Grajewski 2013, 156).

\section{The myth of the German example (see the personal description by Joachim Gauck in Gauck 2009)}

The German model was used as an argument in Poland and other countries, even though that meant disregarding the uniqueness of the German context. As early as December 1989, a genuine social movement rose up in East Germany to keep Stasi archives from being 
destroyed. In Erfurt, Dresden, and Leipzig, demonstrators attacked local secret police headquarters, and on 15 January 1990 East Berliners occupied central Stasi headquarters. Under this pressure from the street, the question immediately arose of how to preserve Communist police documents, along with the issue of what the police had done during the decisive last days of the regime. Between 5 December 1989 and 15 January 1990, all registers and documents concerning police operations were systematically destroyed. The East German roundtable debate was dominated by the question of what was to become of the political police as an organization. Under pressure from the demonstrators, the political opposition rejected transition Prime Minister Hans Modrow's proposal to gradually transform the Stasi. Driven by the desire for an absolute break with the ancien régime, the opposition's initial reflex was to allow the Main Reconnaissance Administration (Hauptverwaltung AufKlärung or HVA) to liquidate all its documents - a nasty blow to policy for managing the Communist past. The only documents saved from destruction were operational files on individuals. A great deal of microfilm and paper-based material was restored using expensive technical procedures that required heavy investments. During this period, the government of the Federal Republic of Germany was also in favor of "resetting" Communist regime archives at close to zero. "At the time," Helmut Kohl later admitted, "I feared that the contents of that septic tank would poison the atmosphere in Germany" (Kohl 2007, 206). But West German politicians only wanted to lock up Stasi archives for an indeterminate length of time, and the collective mobilization got the better of that plan. Within the East German opposition, meanwhile, there was no clear idea what to do with the archives. Joachim Gauck, the first Director of the BStU (Behörde des Bundesbeauftragten für Stasiunterlagen der ehmalingen DDR), recounts that on 4 December 1989, after the demonstrators had taken over Stasi headquarters in Erfurt, their leader Matthias Büchner phoned one of the heads of Neues Forum, Bärbel Bohley: "We're inside the Stasi building - what do we do now?" To which Bohley replied, "It's very simple: everybody takes their personal file, puts it under their arm and goes home."6

\section{The arguments in favor of establishing a similar institution in Poland}

In Poland, the arguments put forward for creating IPN were as follows:

(1) The institution would ensure separation of Communist political police archives and the archives of democratic Poland. The institutional molting or transformation of GKBZH (Glowna Komisja Badan Zbrodni Hitlerowskich) into IPN was necessary to control use of pre-1989 Communist Poland's special service archives; that is, to protect them from the temptation to use personal files in "political games." The point was to prevent politicians from accessing individual files (Traba 2009, 17).

(2) According to the Polish historian Robert Traba, highly critical of IPN, the archives of the Communist special service were supposed to be reserved exclusively "for researchers in history, so they can construct and enrich our knowledge of Communist Poland, its operational mechanisms, the movements that opposed it, and its repression of citizens."7

(3) The law by which IPN was created would render justice to victims of the Communist system and do homage to those who had fought for Poland's freedom and independence. It was in this framework that the status of "victim of Communism" was created. Once a person obtained this status on the grounds of a study of their individual archive, that person was given access to the file and could also have a copy of it. $^{8}$ 


\section{The place and role of the IPN director (Prezes)}

IPN directors were to be selected in such a way as to protect them from political pressure, including from above; that is, from the head of government or any former or current special services. The election, a complex procedure, was designed to guarantee the director a sovereign position within the Polish state hierarchy. A director could not be dismissed unless he or she committed an act harmful to the Institute. The 11-member IPN Collegium (an orientation and steering body) was to be pluralist. To ensure that it was so, the parties represented in the Sejm were to propose nine candidates, to be confirmed by the legislative assembly. The two remaining members were to be named by the National Judicial Council (Krajowa Rada Sadownictwa). The Collegium chooses candidates for IPN director and the Sejm elects one of them. The winning candidate must receive at least three-fifths of the votes. As we shall see, the degree of independence granted to the office had a perverse effect on the second directorship (an election in which the Collegium included only one independent figure, Professor Andrzej Paczkowski). The IPN's second director was free to impose his personal convictions - convictions far from consensual - in the shaping of all IPN public policies.

\section{The first director, Leon Kieres: 2000-2005}

During this period, the institution was feeling its way forward. IPN tasks and operating modes were being clarified and implemented for the first time.

Once again, a crucial issue in IPN institutional operation was archive accessibility. Except for documents deemed non-sensitive, access to archive material was strictly regulated. Consultation reading rooms are kept under close surveillance, in some cases by uniformed guards; locked doors could only be opened in the presence of archivists entrusted with electronic codes. The law of 18 December 1998 by which IPN was created defined the official conditions for archive access. Up until 2005, priority was given to recognized "victims of Communism." Authorized researchers - including journalists - could consult files on specific themes. However, the popular indignation against "unauthorized lustration" provoked by the leaking of the "Wildstein" list - Wildstein was a rightwing journalist - led Director Kieres to deny access to journalists in $2005 .{ }^{9}$ Some observers date the delegitimation of IPN in the eyes of the public from the "unauthorized lustration" action begun by Wildstein. ${ }^{10}$

The status of "victim of Communism" was initially granted to 6500 persons. An estimated 80 kilometers of documents were stocked in IPN archives during this first period.

From 2001 to 2005, the political environment was not always favorable to the Institute, after the parliamentary election won by the post-Communist Party SLD. Here is how Antoni Dudek described the situation some time later:

Kieres was in office during the most difficult period, when the Institute was just getting set up and going into operation. But also and especially when the SLD was in power [Democratic Left Alliance, which developed out of the former communist party]. That party had strong reservations about IPN and sanctioned it every year by blocking attempts to increase its budget allowance. (Dudek 2011, 229) ${ }^{11}$

In 2001, Leszek Miller, leader of the SLD (the former Communists), made it the crux of his campaign to liquidate the Institute. Miller obtained a majority in the Sejm thanks to the coalition with the Peasant Party (PSL) and so could well have done the deed. But his plan was thrown off course by publication of Neighbors, Jan Tomasz Gross's book on the murder of Jews by their Polish neighbors in the village of Jedwabne (Gross 2001). IPN's department of scientific research immediately reacted by setting up a far-reaching field 
study of events during 1941. And at this point, the President of the Republic and former Communist Aleksander Kwasniewski intervened to save IPN because that particular IPN investigation was important to him as part of his "apology diplomacy" and policy of Jewish-Polish reconciliation, a project he held dear. IPN's publication of the results of the study would later be used on several occasions to counter the criticism that the Institute was obsessively anti-Communist. This was well founded given the imbalance of IPN research: much research into Communism and relatively little on Nazism. In any case, Miller's leftwing legislature had to settle for cutting the Institute's budget (Grajewski 2013, 176). From the outset, then, the Institute's fortunes were sensitive to political changeovers.

\section{5 to April 2010: Janusz Kurtyka's term}

Director Janusz Kurtyka, a historian from Krakow, initially ran for the post against another historian, Andrzej Przewoznik. That election was marred by a leak in the press accusing Przewoznik of collaboration. IPN regulations prohibit former political police functionaries or collaborators from applying for the position. Under suspicion of collaboration after a denunciation by a former political police functionary, Przewoznik was forced to withdraw. ${ }^{12}$

In 2006, well into Kurtyka's term, the IPN's three official activities - scientific, judicial, and educational - were expanded by means of a new internal institution called the "Lustration Bureau." The Bureau replaced the Office of the Public Interest Mediator (Rzecznik Interesu Publicznego), previously in charge of lustration cases. And it considerably increased the IPN director's power. It was assigned to check "lustration" statements by all persons holding or wishing to hold public office and to record personal information on former civil servants of the Communist state's repressive apparatuses as well as all individuals whom those apparatuses had sought to recruit as agents. The IPN's judicial function was thereby considerably enlarged and strengthened. Moreover, its employees were called upon to compile catalogs of important figures of the Communist regime, as well as of persons exercising important functions in the democratic regime.

The new director also changed the rules for access to the archives. He dropped the clause on "victims of Communism:" "The abolition of 'victim of Communism' status during the so-called 'moral intensification' period obviously shifted the institution's focus from compensation for victims to interest in collaborating agents" (Friszke quoted in Traba 2009, 19). Without explicitly overturning his predecessor's decision that the archives were to remain off-limits to journalists, Kurtyka authorized their consultation of them on condition that they present a plausible research project and a recommendation from an accredited researcher.

According to Andrzej Friszke, a member of the IPN Collegium for six years, "After 2005, when Janusz Kurtyka became director and Jan Zaryn [a historian who openly presents himself as a rightwing nationalist] took over as head of the Bureau of Public Education, the era of politicization and 'political exclusion' began” (Traba 2009, 19).

It is interesting to note that the IPN's director from 2005 to 2010 had previously served as head of the IPN regional office in Krakow, surrounded by collaborators who "not only shared his scientific interest in the anti-Communist clandestine resistance but also his political opinions. They saw him as both an academic mentor and a continuator of the resistance ... against Communism" (Nowinowski, Pomorski, and Stobiecki 2008, 42).

According to many witnesses, Kurtyka's style of power was absolutist, not to say autocratic. He surrounded himself with colleagues of the same political stripe, that is, close to 
the nationalist-conservative Law and Justice Party (PiS) (Nowinowski, Pomorski, and Stobiecki 2008, 49). For himself and his inner circle, "the struggle against Communism had not ended in 1989 or even with the implosion of the USSR:" "The ghosts of Communism have not yet had a stake driven through their hearts and they continue to roam about among us," wrote the director's closest collaborators, Filip Musial and Jaroslaw Szarek (Nowinowski, Pomorski, and Stobiecki 2008, 49).

This period was characterized by the ideology known as wzmozenie moralne (moral intensification). An explicit "history policy" was put in place (which gave rise to a number of memory-managing policies exalting a romantic, martyrological vision of the Polish nation - in the form of the "Warsaw Uprising" museum, for example). The Institute's political choices during this period were steered by Kurtyka's understanding of the chronology of Polish Communism. As far as he was concerned, the anti-Communist struggle for independence had come to an end with the events of October 1956. All the movements that followed (1968, 1970, 1976, and 1980) were aimed at reforming Communism rather than combating it.

Partisans of Kurtyka's "history policy" dominated the Polish scene from 2005 to 2007 and continued to wield partial power up to 2010. The close relations not to say connivance between the IPN director and the PiS party were an open secret. The politicization of IPN during this period is well illustrated by the words of Prime Minister Jaroslaw Kaczynski to historian members of IPN's Krakow delegation in 2007:

You work on the past, but you are working for the future... The archives assembled together here are of capital importance for what is happening in Poland today.... You are on the front line when it comes to the truth and dignity of our Nation. (Losinska quoted in Czyzewski 2012, 50-51)

Kurtyka was not the least bit troubled by the negative signals he was sending to all groups other than the PiS party. He ostentatiously failed to attend lectures or conferences that had not been organized by the PiS. He did not deign to attend the 2006 conference on martial law, the anniversary conference of the Workers' Defense Committee (KOR), or the conference on the Movement for the Defense of Human and Civil Rights (ROPCiO). ${ }^{13}$

This director conscientiously applied his own history policy, to which he assigned the following polymorphous purposes (Zamorski 2008, 56):

- to serve as an instrument of the political power in both foreign and domestic policy;

- to constitute a particular policy category, the equivalent of foreign, economic, cultural, and internal policy combined;

- to safeguard the national identity through all its activities;

- to be the nation's institution for the defense of collective memory;

- to educate the citizenry.

Meanwhile, opponents of Kurtyka's history policy identified it as: an instrument of oppression and domination used against professional groups such as historians; and an instrument of political manipulation. They also pointed out that when it came to assessing and judging the past, historical policy was subject to the immediate political context, and confused history with politics. ${ }^{14}$

During Kurtyka's term, some researchers were pushed out the door (the scientific director Pawel Machcewicz was replaced by Jan Zaryn, the latter known for his sympathies with the nationalist group "Endecja”). Many good researchers who were judged excessively heterodox quit IPN, and researchers with convictions close to those of the director were recruited to replace them (Janusz Marszalec, Dariusz Libionka, Stanislaw Jankowiak, 
Rafal Wnuk, and Grzegorz Motyka were replaced by Piotr Gontarczyk, Slawomir Cenckiewicz (who was later dismissed), and Filip Musial).

We see here the influence of the postulate that the director dictates what's what. The undertaking is summed up well in the following words of the conservative Krakow historian Andrzej Nowak: "We had to construct a counter-narrative to the historical discourse of the 1989 political victors. Their discourse dominated for over 20 years, with a single interruption - from 2005 to 2007 - and it created structures of domination in historical research." 15

\section{1-2014: Lukasz Kaminski's term as director: refocusing and changing course}

The third director, Lukasz Kaminski, was elected in tragic circumstances: Janusz Kurtyka died on 10 April 2010, in the plane crash in Smolensk that killed the Polish president. Kaminski, a historian, was an institution insider who had already headed IPN's Regional Bureau of Public Education (Oddzialowe Biuro Edukacji Publicznej or OBEP) in Wroclaw. During his term, the IPN institution came under a wide barrage of criticism, leading its partisans to fear it would lose not only its legitimacy but also its raison d'être. ${ }^{16}$ It was as director of the Wroclaw Regional Bureau in charge of scientific projects - he had not yet been elected IPN Director but knew he would be - that Kaminski, in his closing remarks to a conference devoted to assessing the preceding decade of IPN activities, often in sharply critical terms, put forward the following credo:

The first component [of the Institute's future policy] is understanding that we must not undertake a total revolution. This means that we must not try to change everything. As far as I'm concerned, making a revolution in the Institute every five years will not have the desired effect.

Further on, he specified: "We have to be careful that the patient does not die during the operation rather than recovering his health and functioning better once he's recovered" (Kaminski quoted in Czyzewski 2012, 402-405).

\section{Criticisms}

The increasing amount of criticism has led some observers to conclude that IPN should be entirely overhauled; others that it should be replaced by other institutions. Criticism has focused on two points: structural anomalies and malfunctioning; and issues around content, methodology, ethics, and epistemology.

The main criticism concerns the fact that the Institute is a state institution. Some go so far as to call it the National Memory Ministry. Lumping together departments with overly distinct if not downright incompatible tasks in the same institution - for example, investigative prosecutors and the lustration office alongside the department for education and research - produces a huge amount of bureaucracy. According to Dariusz Stola, a moderate historian not at all hostile to IPN, it is because the Institute is part of the state administration that it recreates state administration-type problems; above all an oversized administrative staff (30\% of all personnel) to serve researchers and other civil servants on specific missions. Stola also points to the problem with the director's status: being independent of the other organs of state was necessary at moments when former Communists could attack the institution's function, but at other times it is dangerous. It means that too much hangs on the director's personality. In this connection, Stola recalled Janusz Kurtyka's tendency to impose his version of history and marginalize anyone who dared criticize it. ${ }^{17}$ 
Another source of malfunction has to do with the body of prosecutors assigned to check into individuals' pasts. The historians and archivists in charge of preparing the legal cases are often appalled at the jurists' ignorance of history. The prosecutors, meanwhile, with their own set of administrative and professional practices and strong sense of their exceptionality, avoid contact with historians. Animosity between different staff categories is exacerbated by unequal pay: prosecutors' salaries are several times higher than those of researchers or archivists.

The IPN budget contrasts sharply with the resources allotted to university institutes. With 200 million zlotys per year, including 30 million for academic research, the Institute has a virtual monopoly over the 1939-1990 period of history. It is pointed out that though the Gauck Office, the ideal model, receives much more substantial funding than its Polish counterpart (90 million euros in 2011), several other German institutes and foundations also enjoy hefty allocations, and this guarantees pluralism and freedom of discussion in historical research.

Antoni Dudek notes another institutional anomaly dating from the 2005-2010 period:

A group [of historians] within IPN but also from outside it became intoxicated with exploring all these documents. They thought they had found "a magic key" for understanding more recent history, a key that will unlock all its secrets. They behaved a little like the sorceror's apprentice; they had no idea how ridiculous they looked. Worse yet, they rejected any attempt to make them see it, as if one had attacked their ethical or patriotic mission to discover the truth. (Dudek quoted in Czyzewski 2012, 375)

Academic researchers and former IPN personnel alike readily criticize the Institute's intellectual production. In addition to pointing up a gross imbalance between the quality studies it publishes and the massive amount of writing of no real scientific interest it also publishes, critics note the thematic monotony of IPN research. The number of micro-historical studies, whose methodology is debatable, greatly exceeds that of broader-scope quality works. "As time passed, my closets filled up with ever-poorer publications," remarks historian Antoni Dudek; and "[I noted] a multiplication of studies whose length was inversely proportional to the interest of the subject;" "the review process that every submission is supposed to go through became a fiction and proceeded on a you-scratch-my-back-I'll-scratchyours basis: 'I'll write you a good review if you do the same for me;", "the rare good books that get published are drowned in a few hundred publications of less than modest scientific worth" (Dudek quoted in Czyzewski 2012, 397).

There is also concern about the patent domination of the martyrology motif in IPN production: dualist simplifications summed up by the "political power vs. society" opposition wherein the political authorities are demonized and society is represented as a monolith: the Nation. And there are many areas in which little research is done at all, such as the social history of Communism, sociology of the political elite, and study of the processes that worked to legitimate the Communist system.

An entire cluster of criticisms target methodology, epistemology, and ethics. Some examples: "lack of standards for analyzing political police archives; e.g. police language is used without quotation marks;" "no comparison [of IPN material] with other sources in other archives and libraries." Critics complain that the propensity to think of IPN resources as exceptional or unique has led to a lack of critical distance and the ubiquitous belief that "only direct sources contain the absolute truth." IPN research isolationism has been attacked for convincing people that epistemological normalization is impossible and that there is therefore no need to read or cite the international literature.

In response to these criticisms, the new director has made significant changes. $\mathrm{He}$ responded to the accusation of IPN isolationism by organizing a public debate among 
historians, including those not working at the Institute. New voices were heard, and their accounts differed from the one given by IPN officials, as attested by Antoni Dudek's book but also by several IPN researchers who participated in the debate. Their critical assessments are now included in works published by the IPN itself, an example being the collection of papers given at the Tenth Anniversary Conference with its suggestive, symbolic title "No flat rate" (Bez Taryfy ulgowej), here meaning "Go ahead and criticize us freely; we'll even publish what you have to say." Symptomatically, the organizers of that conference repeatedly refer to it as "the historiographical audit."

And in an attempt to stave off the criticism, Kaminski has suggested refocusing on the general issue of victims, which his predecessor turned away from in favor of "an agent hunt." The IPN website, meanwhile, is now responding to criticisms by publishing denials and explanations.

However, these worthwhile attempts to improve the situation have not prevented new excesses and blunders.

\section{Conclusion}

The subject here has not been memory itself but the institutions devoted to it, institutions that manage memory by means of carefully guarded archives, the cases they build against agents responsible for the crimes and persecutions of the two totalitarianisms, and the educational function they are called upon to perform.

Their names may be a source of semantic confusion. Are they devoted to memory, or are they instead historical research institutes in the academic sense of the term? In fact, their hybrid nature - a combination of history and memory - is already a problem in itself. At no time does the idea seem to have come to mind that it would be useful to clarify the question of these two fields and therefore the relationship between memory and history. This is one major cause of the political-institutional ambiguity attaching to these institutions. Some speak of historians working on historian-generated narratives; others of the duty and labor of remembering. But the very structure of these institutions combines the two, probably because their founding laws were not clear. The cornerstone of these institutions is their archives, but those archives are used in several different types of actions: historians use them to substantiate historical accounts; they are used as proof in determining who is a victim and who an executioner but also to fuel memory and even to determine a memory-based representation of the past to be transmitted, commemorated, and processed into educational material. Not to mention all the possible illicit uses of the archives, such as composing non-official lists of supposed collaborators or using documentation to reveal sensitive information for the purpose of political stigmatization.

If we want to explore relations between these institutions and Communist memory, we have several theoretical schemata or paradigms to choose from, but the one that seems almost spontaneously the most relevant is neo-institutionalism, since we are dealing with a bureaucratic institution in Max Weber's sense, with its internal and external dynamics. Neo-institutionalism allows for injecting a considerable dose of dynamic sociology into this analytic framework. Though biographical-type studies are beyond the scope of this article, we can focus on interactions between internal and external actors and between the institution and its general socio-political context.

From this perspective, at least two conclusions seem justified. First, changes in judiciary and political context affect the "healthy functioning" of the institution. Second, politicization of internal organization and the post of director gives rise to adaptations that nonetheless do not change the essence of the institution. 
My analysis here has sought to answer the question "Can the path of this type of institution, an institution in charge of historical and memory policies, be corrected?" We have seen that the institution remains in place regardless of who is at its head and how it is run. The third conclusion thus follows logically: radical change can only come from an institutional transformation that would consist in separating action repertoires and structurally dividing the institution into two or three institutions: a history institute, an institute for educational transmission and dissemination, and an appropriate legal body. But this in turn could only be done if the left were to come to power in Poland - a highly unlikely event.

The successive governments have done all in their power to save the Institution from dismantlement, as attested by the new law on IPN governance, in force since the election victory of the Civic Platform Party. And the IPN continues to serve as a memory "mine" for internal and external partisan actions and uses.

Let me conclude by citing two deeply involved actors whose contradictory opinions clearly indicate the extremes of Polish elite opinion on what is to be done with the IPN:

Liquidating the IPN by breaking it up (the SLD project) at a time when other countries are creating precisely this type of institution would mean that we Poles, who were able to destroy communism, are not capable of putting paid to the communist past. (Krzysztof Persak, Gazeta Wyborcza, 11 September 2012, 11)

Studying the past is not the point, especially since objectivity is not the point here.... By opposing IPN we restore transparency to Polish social life. And thereby say "yes" to Polish democracy. (Andrzej Romanowski, specialist of Polish literature and historian, Gazeta Wyborcza, 11 September, 2012, 11)

\section{Epilogue}

On 16 June 2016, the new PiS majority, in power since Andrzej Duda was elected President of the Republic and the PiS won both the Sejm and the Senate, voted to change the law on IPN. Specifically, the procedure for electing the IPN Director was redefined. Whereas until now the Director was elected by the relatively pluralist IPN Council by way of an internal contest, that Council has now been replaced by a nine-member College composed exclusively of PiS members or loyal supporters; the Sejm elects the Director after consultation with the College (no competition among contenders) and on condition of Senate approval. Obviously, the new Director will obey the PiS majority in all things. The described tendency is confirmed, even more radically after the election of the new Director Jaroslaw Szarek. ${ }^{18}$

\section{Notes}

1. Pytlakowski 2014. I used this concept in my analysis of memory games in "post-Communist" countries in the context of EU enlargement (Mink and Neumayer 2013).

2. Decree of 18 December 1998, on the Institute of National Remembrance-Commission for the Prosecution of Crimes against the Polish Nation (Dziennik Ustaw, 1998, 155, position 1016, modified in the Dziennik Ustaw, 1999, 38, position 360). But the IPN started to be organized only in mid-2000s.

3. Adam Michnik exposé during the conference at the University of Michigan University, 7-10 April 1999, https://webapps.lsa.umich.edu/ii/polishroundtable/pdf/rtssession2polish.pdf.

4. Decree of 23 February 1991 (Dziennik Ustaw, 1991, 34, position 149).

5. Information available on the IPN website (Biuletyn IPN 2: 22, Warsaw, 2013).

6. Talk by Gauck at the "De-communization" conference held at the Polish Sejm, 10-12 December 1999. 
7. Remark made on the occasion of the Tenth IPN Anniversary Conference, December 2010. Andrzej Friszke, a moderate historian identified with the center-left who participated in IPN studies but was critical of the institution, recalled that on the positive side it had hired a few dozen fine young historians, former students who had written good Masters theses and graduated from the country's most highly reputed universities.

8. This status was abolished when the PiS-LPR-Samoobrona coalition, identified as nationalistpopulist, was in power (2005-2007).

9. In January 2005, the journalist Bronislaw Wildstein, a member of the movement demanding that former agents be checked at last and de-communization made real and effective, slipped out of the IPN reading room with a catalogue - a tool required for locating personal files. The catalogue contained personal information on several categories of persons: people who had effectively collaborated with the secret police were listed together with persons who the police were hoping to recruit and some names that were there for no reason. The list immediately began to circulate on the internet (see https://en.wikipedia.org/wiki/Wildstein list). See also Dudek $(2011,30)$.

10. In August 2005, another legal barrier to file access was put up, this time by the general inspector for personal data privacy. Applicants now had to justify being given access to personal information about themselves. This did not prevent unauthorized consultations, however.

11. Dudek was a member of IPN from 2000 to 2011, working first as head of the scientific research department, then, from 2005, as advisor to Janusz Kurtyka, the second director. He is a staunch supporter of the institution, but he does allow himself to criticize some aspects of its operation.

12. Przewoznik was cleared of dissimulating collaboration in November 2005 but it was too late to change the election proceedings. Kurtyka later explained that he had authorized access to documents that would compromise Przewoznik's chances (Dudek 2011, 234).

13. KOR (Workers' Defense Committee) was formed following the revolt of Polish workers in 1976 to ensure legal and material assistance to victims of government repression while ROBCIO (Movement for the Defense of Human and Civic Rights) was a center-right anti-Communist, autonomist organization founded in 1977.

14. Some Polish historians have been receptive to the attitude of French historian associations about the profusion of memory laws and the intrusion of politics in history during Nicolas Sarkozy's term as president. See Zamorski $(2008,56)$ :

The objections of professional historians concerning the effects of 'historical policy' is perfectly expressed in the following declaration by French historians:

(1) history is not morality: historians do not judge, condemn or magnify; they explain;

(2) history is not memory; historians are conscious of the weight of memory but their work is to find evidence to back up an account that complies with the norms established by the academic profession;

(3) history is not a subject in law; in a democratic country, the search for historical truth is not a matter for parliamentary or judicial decisions or rulings;

(4) state policy shall not be historical in nature.

15. Andrzej Nowak pronounced this sentence during the special session organized by the President Andrzej Duda, 16 February 2016, dedicated to the new historical policies imposed by the program of the ruling Law and Justice Party.

16. Should the left come to power in Poland (a very unlikely occurrence in any near future), IPN would certainly be dissolved and its archives transferred to the Archivum Akt Nowych. This is the oft-mentioned plan (with some variations) of the entire spectrum of left-identified parties.

17. I paraphrase here the speech done by Dariusz Stola during the conference dedicated to the 10th anniversary of the existence of IPN in December 2010, from Bez Taryfy ulgowej, 381-393.

18. See http://www.polskatimes.pl/aktualnosci/a/sejm-uchwalil-nowelizacje-ustawy-o-instytuciepamieci-narodowej,9936870/.

\section{References}

Czyzewski, Andrzej, Slawomir M. Nowinowski, Rafal Stobiecki, and Joanna Zelazko. eds. 2012. Bez taryfy ulgowej [No Flat Rate]. Lodz: IPN. 
Dudek, Antoni. 2011. Instytut, osobista historia IPN [Institute: The Personal History of IPN]. Warsaw: Czerwone i Czarne.

Gauck, Joachim (with Helga Hirsch). 2009. Winter im Sommer - Frühling im Herbst. Erinnerungen [Winter in Summer, Spring in Autumn, Memories]. Munich: Siedler Verlag.

Grajewski, Andrzej. 2013. "Balast po komunizmie. Instytucjonalne rozliczenie komunizmu w krajach Europy Srodkowej." [The Weight of the Communist Legacy in Central Europe.] Pamiec $i$ Sprawiedliwosc, February: 156.

Gross, Jan T. 2001. Neighbors: The Destruction of the Jewish Community in Jedwabne, Poland. Princeton, NJ: Princeton University Press.

Kohl, Helmut. 2007. Erinnerungen 1990 bis 1994 [Memories from 1990 to 1994]. Munich: Droemer.

Mink, Georges, and Laure Neumayer. eds. 2013. History, Memory and Politics in Central and Eastern Europe, Memory Games. Basingstoke: Palgrave Macmillan.

Nora, Pierre. 1984. Les lieux de mémoire. Paris: Gallimard. Published in English 1997 under the title Realms of Memory, translated by Arthur Goldhammer, vol. 1. Chicago, IL: University of Chicago Press.

Nowinowski, Slawomir M, Jan Pomorski, and Rafal Stobiecki. eds. 2008. Pamiec i Polityka Historyczna [Memory and Historical Policy]. Lodz: IPN.

Pytlakowski, Piotr. 2014. "Przemysl wydobywczy IPN [IPN Extraction Industry]." Polityka, February 19-25: 18-19.

Romanowski, Andrzej. 2012. "IPN, Dziwolag ponad panstwem [IPN: Strange Creature Above the State]." Gazeta Wyborcza, September 11: 11.

Traba, Robert. 2009. Przeszlosc w terazniejszosci, Polskie spory o historie na poczatku XXI wieku [The Past in the Present Time, The Polish Quarrels About the History in the Beginning of the XXI Century]. Poznan: Wydawnictwo Poznanskie.

Zamorski, Krzysztof. 2008. Pamiec i Polityka Historyczna [Memory and Political History]. Lodz: IPN. 